\title{
Impact of post harvest treatment on antioxidant activity and phenolic profile of Moringa oleifera lam leaves
}

\author{
Edith N. Fombang ${ }^{1 *}$ D, Pierre Nobossé ${ }^{1,2}$, Carl M. F. Mbofung ${ }^{1}$ and Damanpreet Singh ${ }^{2}$
}

\begin{abstract}
Moringa oleifera leaves are an important source of dietary phytochemicals, such as flavonoids with high antioxidant activity (AOA). These components are however influenced by the post-harvest treatments applied as well as the processing conditions. Hence, it is crucial to determine the most appropriate post-harvest treatment that preserves or enhances AOA. To this effect the influence of steam blanching, fermentation / oxidation, oven drying and roasting of fresh Moringa leaves on their AOA was investigated. Processing conditions of time and temperature for each treatment were optimised using response surface methodology. The effect of the different treatments at optimal conditions on phenolic profile and AOA were compared. Roasting achieved the most significant $(p<0.05)$ improvement in phenolics (43\%) and AOA (22-31\%), which was accompanied by the formation of 2 new compounds, quercetin-3-O-acetylglucoside and Quercetine-3-O-rhamnoside. Steam blanching had the most deleterious effect on phenolics (-31\%) and AOA. Post-harvest treatments qualitatively and quantitatively affect phytochemical profile of Moringa leaves.
\end{abstract}

Keywords: Moringa oleifera leaves, Post harvest treatment, Optimisation (response surface methodology), Phenolic profile, Antioxidant activity

\section{Introduction}

Moringa oleifera is a drought resistant and fast growing tree, present in most tropical and sub-tropical countries. Moringa leaves have been used for centuries for nutritional and medicinal purposes, due to their high content of essential disease-preventing nutrients such as vitamins, minerals, protein and antioxidants. The leaves can be eaten fresh, cooked, or stored as dried powder (Gopalakrishnan et al. 2016).

Moringa oleifera leaves are an important source of dietary phytochemicals endowed with high antioxidant activity (Agamou et al. 2015; Nobossé et al. 2018). Previous work (Nobossé et al. 2018) revealed 45-day-old leaves as having the best antioxidant activity. However,

\footnotetext{
* Correspondence: edfombang@yahoo.fr

'Department of Food Science and Nutrition, National School of Agro-Industrial Sciences, ENSAI, University of Ngaoundere, P.O. Box 455,

Ngaoundere, Adamawa Region, Cameroon

Full list of author information is available at the end of the article
}

several studies have indicated that post-harvest treatments such as drying (Moyo et al. 2017; Nobossé et al. 2017; Potisate et al. 2014), roasting (Parwani et al. 2016), steam blanching (Nobossé et al. 2017) and water blanching (Moyo et al. 2017; Potisate et al. 2014) affect antioxidant activity of $M$. oleifera leaves. Other treatments such as fermentation/oxidation (Kim et al. 2011; $\mathrm{Ng}$ et al. 2021; Samanta et al. 2013) and cooking (Miglio et al. 2008; Moyo et al. 2017) have equally been shown to affect antioxidant activity of tea and leafy vegetables respectively. These findings suggest the need for the determination of the most appropriate post-harvest treatment for the preservation or enhancement of AOA in M. oleifera leaves.

Steam blanching and cooking results in matrix softening that could improve extractability of antioxidant components from plant materials (Feumba Dibanda et al. 2020; Palermo et al., 2013; Wang et al. 2021). On the

(c) The Author(s). 2021 Open Access This article is licensed under a Creative Commons Attribution 4.0 International License, which permits use, sharing, adaptation, distribution and reproduction in any medium or format, as long as you give appropriate credit to the original author(s) and the source, provide a link to the Creative Commons licence, and indicate if changes were made. The images or other third party material in this article are included in the article's Creative Commons licence, unless indicated otherwise in a credit line to the material. If material is not included in the article's Creative Commons licence and your intended use is not permitted by statutory regulation or exceeds the permitted use, you will need to obtain permission directly from the copyright holder. To view a copy of this licence, visit http://creativecommons.org/licenses/by/4.0/. 
other hand, enzymatic oxidation of native plant polyphenols and their possible reorganization into condensed derivatives, can either enhance, preserve or decrease antioxidant activity depending on their nature (Heong et al. 2011; Kim et al. 2011; Kongpichitchoke et al. 2016). Likewise, roasting operation has been reported to be accompanied by non-enzymatic browning reactions resulting in the formation of Maillard reaction products (Zhang et al. 2016) as well as the polymerization of native polyphenols leading to the formation of higher molecular weight polyphenolic derivatives (Juániz et al. 2016). In addition to their effect on phenolic content, post-harvest treatments could affect the phenolic profile in vegetables (Al-Juhaimi et al. 2018). It is however important to note that the influence of processing method depends on processing conditions. Therefore, to select the appropriate post-harvest treatments for Moringa oleifera leaves, it is necessary to first of all determine the optimal processing conditions for each treatment. For this purpose, response surface methodology (RSM) was used to explain the effect of independent variables, alone or in combination, on AOA in Moringa oleifera leaves.

RSM consists of a group of mathematical and statistical techniques containing a statistical experimental design often used to define the relationship between the response and the independent variables. In addition to analyzing the effects of the independent variables, this experimental methodology also generates a mathematical model that can be used for optimization (Bas \& Boyacl 2007). Hence, the present study used the Doehlert experimental design in RSM to optimise experimental conditions (time and temperature) of steam blanching, fermentation/oxidation, drying and roasting for maximum AOA in Moringa oleifera leaves; and to further compare the effect of different post-harvest treatments at optimal conditions on AOA, phenolic content and profile in Moringa oleifera leaves. The ultimate goal here was to select the most appropriate post-harvest treatment, with its optimal conditions for which antioxidant activity of Moringa oleifera leaves is improved or preserved.

\section{Material and methods \\ Plant material}

Fresh Moringa oleifera leaves, $45 \pm 5$ days old, were harvested from our experimental garden in Ngaoundere, Adamawa Region, Cameroon and immediately transported to the Food Biophysics, Biochemistry and Nutrition laboratory of the National School of AgroIndustrial Sciences (ENSAI) of the University of Ngaoundere. The leaves were sorted to remove extraneous material, washed with clean free flowing tap water and drained.

\section{Optimization of post-harvest treatment of fresh Moringa} oleifera leaves

Response surface methodology (RSM), defined earlier, was used to obtain optimal conditions of post-harvest treatments (drying, steam blanching, fermentation/oxidation and roasting) that maximize AOA of fresh Moringa leaves. The experimental design consisted of two factors namely, temperature $\left(\mathrm{X}_{1},{ }^{\circ} \mathrm{C}\right)$ and time $\left(\mathrm{X}_{2}, \mathrm{~min}\right)$. The lower, middle and upper levels of factors considered for optimization in coded and uncoded (actual) values are shown in Table 1. The response variables for optimization were AOA using the DPPH radical scavenging activity and total antioxidant capacity (TAC) by the phosphomolybdenum assay. The experimental domain was selected based on preliminary experiments. A twofactor Doehlert experimental design (Table 2) consisting of nine experimental runs including two replicates at the center point was used for every post-harvest treatment. The experimental runs were performed in a totally random order to minimize effects of non controlled factors and triplicate experiments were carried out at all design points.

\section{Steam blanching of Moringa leaves}

Fresh Moringa leaves were steamed at $80-100{ }^{\circ} \mathrm{C}$ for 5 to $15 \mathrm{~min}$ (Tables 1 and 2) in a domestic steam cooker (SEB, France). The steamed leaves were allowed to cool at $25^{\circ} \mathrm{C}$ and then finely ground in a ceramic mortar into a smooth paste prior to extraction.

\section{Fermentation/oxidation of Moringa leaves}

Fresh Moringa leaves were slightly crushed to bring enzymes in contact with substrate to accelerate oxidation of polyphenols. This process was used to simulate what happens during the production of black tea $(\mathrm{Ng}$ et al. 2021). The crushed leaves were placed in an incubator (Memmert GmbH, Germany) at the indicated temperature and time derived from the Doehlert experimental matrix (Tables 1 and 2). The oxidised/fermented leaves were finely ground in a ceramic mortar into a smooth paste prior to extraction.

\section{Drying of Moringa leaves}

Fresh $M$. oleifera leaves were spread in a thin layer on aluminium trays and dried in a moisture analyzer (DENVER IR-35 Infrared Moisture Analyzer) at 40$70{ }^{\circ} \mathrm{C}$ for 180 to $210 \mathrm{~min}$ (Tables 1 and 2). The dried leaves were ground using a blender (Moulinex Model LM242027) and sieved through a $500 \mu \mathrm{m}$ sieve to obtain the Moringa dried leaf powder.

\section{Roasting of Moringa leaves}

Moringa leaves were spread on stainless steel trays $(1 \mathrm{~g} /$ $20 \mathrm{~cm}^{2}$ ) in a torrefier (BCM TORRE PICENARDI (CR) 
Table 1 Experimental domain and independent variables for optimization

\begin{tabular}{|c|c|c|c|c|}
\hline & $\begin{array}{l}\text { Factors (Symbol, } \\
\text { Units) }\end{array}$ & $\begin{array}{l}\text { Lower } \\
\text { level }\end{array}$ & $\begin{array}{l}\text { Middle } \\
\text { level }\end{array}$ & $\begin{array}{l}\text { Upper } \\
\text { level }\end{array}$ \\
\hline \multirow[t]{2}{*}{ Drying } & $\begin{array}{l}\text { Temperature }\left(\mathrm{X}_{1} \text {, }\right. \\
\left.{ }^{\circ} \mathrm{C}\right)\end{array}$ & 40 & 55 & 70 \\
\hline & Time $\left(X_{2}, \min \right)$ & 180 & 195 & 210 \\
\hline \multirow[t]{2}{*}{ Roasting } & $\begin{array}{l}\text { Temperature }\left(X_{1},\right. \\
\left.{ }^{\circ} \mathrm{C}\right)\end{array}$ & 140 & 160 & 180 \\
\hline & Time $\left(X_{2}, \min \right)$ & 5 & 15 & 25 \\
\hline \multirow[t]{2}{*}{ Steam blanching } & $\begin{array}{l}\text { Temperature }\left(X_{1},\right. \\
\left.{ }^{\circ} \mathrm{C}\right)\end{array}$ & 80 & 90 & 100 \\
\hline & Time $\left(X_{2}, \min \right)$ & 5 & 10 & 15 \\
\hline \multirow[t]{2}{*}{$\begin{array}{l}\text { Fermentation/ } \\
\text { Oxidation }\end{array}$} & $\begin{array}{l}\text { Temperature }\left(X_{1}\right. \\
\left.{ }^{\circ} \mathrm{C}\right)\end{array}$ & 25 & 35 & 45 \\
\hline & Time $\left(X_{2}, \min \right)$ & 15 & 52.5 & 90 \\
\hline
\end{tabular}

Italy, Model Panacea 2430) and roasted at $140-180^{\circ} \mathrm{C}$ for 5 to $25 \mathrm{~min}$ (Tables 1 and 2). The roasted leaves were ground using a blender (Moulinex Model LM242027) and sieved using a $500 \mu \mathrm{m}$ sieve to obtain the roasted leaf powder. The paste and powder samples were stored at $-20^{\circ} \mathrm{C}$ prior to analysis.

\section{Comparison of post-harvest treatments}

In order to identify the most appropriate post harvest treatment that best improves AOA for Moringa leaves, fresh samples were compared with samples treated under defined optimal processing conditions of blanching, fermentation/oxidation, drying and roasting. The treated samples were analyzed for polyphenolic content, phenolic profile and AOA using the DPPH, ABTS, TAC, Ferric Reducing Antioxidant Power (FRAP) assays.

\section{Modelling}

Data obtained in the experimental design were fitted to a full second-order polynomial model (Eq. 1) and the coefficients of the model equation determined.

$$
\begin{aligned}
\mathrm{Y}= & \mathrm{b}_{0}+\mathrm{b}_{11} \mathrm{X}_{1}^{2}+\mathrm{b}_{22} \mathrm{X}_{2}^{2}+\mathrm{b}_{12} \mathrm{X}_{1} \mathrm{X}_{2}+\mathrm{b}_{1} \mathrm{X}_{1} \\
& +\mathrm{b}_{2} \mathrm{X}_{2}
\end{aligned}
$$

Where $\mathrm{Y}$ is the dependent variable; $\mathrm{b}_{0}, \mathrm{~b}_{1}, \mathrm{~b}_{2}, \mathrm{~b}_{11}, \mathrm{~b}_{12}$ and $b_{22}$ are regression coefficients; and $X_{1}, X_{2}$ are independent variables.

The prediction model is useful for estimating responses at different levels of independent variables within the range of variables from which the model equation was generated.

\section{Validation and verification of the generated models}

The validity of the models was checked using statistical tools such as lack-of-fit, coefficient of determination $\left(\mathrm{R}^{2}\right)$, absolute average deviation (AAD) and bias $\left(\mathrm{B}_{\mathrm{f}}\right)$ and accuracy $\left(\mathrm{A}_{\mathrm{f}}\right)$ factors. AAD is given by Eq. 2 while $\mathrm{A}_{\mathrm{f}}$ and $B_{f}$ are respectively given by Eqs. 3 and 4 . Furthermore, the practical verification of the models was done by comparing experimental and predicted values at a selected point in the optimal area.

The suitability of the quadratic models for prediction was estimated through the verification experiments performed in the optimal area obtained for every postharvest treatment. Subsequently, the experimental and predicted values of the response were compared to estimate the levels of suitability of models.

$$
\begin{aligned}
& A A D=\left[\sum_{i=1}^{p}\left(\frac{\mid Y i, \exp -Y i, \text { cal } \mid}{Y i, \exp }\right)\right] / p \\
& B_{f}=10^{\frac{1}{p} \sum_{i=1}^{p} \log \left(\frac{Y, c a l}{Y_{i}, e x p}\right)} \\
& A_{f}=10^{\frac{1}{p} \sum_{i=1}^{p}\left|\log \left(\frac{Y_{i}, \text { ala }}{Y i, \text { exp }}\right)\right|}
\end{aligned}
$$

\begin{tabular}{|c|c|c|c|c|c|c|c|c|}
\hline \multirow[b]{2}{*}{ Runs } & \multicolumn{2}{|l|}{ Drying } & \multicolumn{2}{|l|}{ Roasting } & \multicolumn{2}{|c|}{ Steam blanching } & \multicolumn{2}{|c|}{ Fermentation/Oxidation } \\
\hline & Temperature & Time & Temperature & Time & Temperature & Time & Temperature & Time \\
\hline 1 & 55 & 195 & 160 & 15 & 90 & 10 & 35 & 52.5 \\
\hline 2 & 55 & 195 & 160 & 15 & 90 & 10 & 35 & 52.5 \\
\hline 3 & 55 & 195 & 160 & 15 & 90 & 10 & 35 & 52.5 \\
\hline 4 & 70 & 195 & 180 & 15 & 100 & 10 & 35 & 90 \\
\hline 5 & 40 & 195 & 140 & 15 & 80 & 10 & 35 & 15 \\
\hline 6 & 63 & 210 & 170 & 25 & 95 & 15 & 45 & 71.25 \\
\hline 7 & 63 & 180 & 170 & 5 & 95 & 5 & 25 & 71.25 \\
\hline 8 & 48 & 180 & 150 & 5 & 85 & 5 & 25 & 33.75 \\
\hline 9 & 48 & 210 & 150 & 25 & 85 & 15 & 45 & 33.75 \\
\hline
\end{tabular}

Where Yi,exp. and Yi,cal are the experimental and calculated responses, respectively, and $\mathrm{p}$ is the number of the experimental run.

Table 2 Doehlert design showing experimental runs for every post-harvest treatment

Temperature $\left({ }^{\circ} \mathrm{C}\right)$, Time (minutes) 


\section{Optimization procedure}

The multiple response optimization allows a compromise where all response variables are simultaneously optimal within the studied range of independent variables. Hence, after generating and validating the prediction polynomial models linking the responses to the independent variables studied, the optimization procedure was performed to obtain the optimal levels of factors required to have maximum AOA. For this purpose, the fitted polynomial models were expressed as threedimensional contour plots in order to visualize the relationship between the response variables and the levels of every independent variable and to deduce the optimum conditions. The multiple response optimization procedure was performed by manually superimposing the contour plots from every response variable into a single graph and the area where both response variables were simultaneously optimal was selected as optimum area and hatched.

\section{Experimental procedure Extraction}

The processed (steam blanched, fermented/oxidised, dried and roasted) ground samples from the different experimental runs were macerated in $95 \%$ ethanol $(1 / 40$, $\mathrm{m} / \mathrm{v}$ ) in a conical flask. The flask was sealed with laboratory film (parafilm $\mathrm{M}$ ) and the mixture was mechanically stirred for $2 \mathrm{~h}$ at $25 \pm 2{ }^{\circ} \mathrm{C}$ using a magnetic stirrer $(60$ $\mathrm{Hz}$ ) and centrifuged at $2300 \mathrm{~g}$ for $30 \mathrm{~min}$ at $4{ }^{\circ} \mathrm{C}$ (Anke, DL6000 B, Japan). The supernatant was used for determination of DPPH radical scavenging activity and total antioxidant activity. From these results, the optimal time-temperature set of each treatment was determined.

After obtaining the optimal conditions for each treatment, fresh Moringa oleifera leaves were processed in these optimal conditions, then extracted with ethanol as above and concentrated in a rotary evaporator at $50{ }^{\circ} \mathrm{C}$. The concentrated extracts were freeze dried and stored at $4{ }^{\circ} \mathrm{C}$ until analysis.

For each extract, a stock solution of $10 \mathrm{mg} / \mathrm{mL}$ was prepared in ethanol. Several dilutions were further prepared from the stock solution to make working solutions which were used in antioxidant activity assays. Other assays performed were total phenolic and flavonoids content.

\section{Phytochemical content of Moringa leaves Total phenolic compounds}

Total phenolic compounds (TPC) of the extracts was determined as reported previously (Nobossé et al. 2017) using the Folin-Ciocalteu's phenol reagent, with gallic acid as standard. TPC was expressed as gallic acid equivalents in $\mathrm{mg} \mathrm{GAE} / \mathrm{g}$ of extract.

\section{Total flavonoids content}

Flavonoids were determined according to the method described by Nobossé et al. (2017). Catechin $(0.01 \%)$ was used as standard, and the flavonoid content was expressed as catechin equivalent (CE) in $\mathrm{mg} \mathrm{CE} / \mathrm{g}$ of extract.

\section{Antioxidant properties of Moringa leaves $D P P H$ radical scavenging activity assay}

The DPPH scavenging activity was measured according to the method of Brand-Williams et al. (1995) as described by Nobossé et al. (2017). The DPPH scavenging activity (\%) was plotted against extract concentration and the $\mathrm{IC}_{50}$ value $(\mathrm{mg} / \mathrm{ml})$ of each extract calculated. The calculated $\mathrm{IC}_{50}$ value denotes the concentration of the sample required to scavenge $50 \%$ of free radicals.

\section{$A B T S^{+}$radical scavenging activity}

$\mathrm{ABTS}^{+}$radical scavenging activity was determined following the method of $\operatorname{Re}$ et al. 1999, reported by Nobossé et al. (2018). The ABTS radical scavenging activity was calculated as percent inhibition and plotted against sample concentrations and the $\mathrm{IC}_{50}$ value of each extract was calculated. Ascorbic acid was used as reference antioxidant.

\section{Total antioxidant capacity (TAC)}

The TAC was evaluated by the phosphomolybdenum assay of Prieto et al. (1999). This assay is based on the reduction in Mo (VI) to Mo $(\mathrm{V})$ by the sample analyzed and the subsequent formation of a green phosphate/Mo (V) complex at acidic $\mathrm{pH}$. Ascorbic acid was used as standard. The antioxidant activity was expressed as ascorbic acid equivalent (g AAE/100 g DM) for optimisation, and for the extract of processed samples at optimal conditions as mg AAE/g of extract.

\section{Ferric-reducing antioxidant power (FRAP)}

The Ferric reducing antioxidant power of $M$. oleifera leaf extract was determined by the method using potassium hexacyanoferrate, as described by Nobossé et al. (2017). Ascorbic acid was used as a reference.

\section{UPLC-ESI- QTOF-MS of Moringa leaf extracts}

The phenolic profile of fresh and processed (dried, steam blanched, fermented/oxidised and roasted) Moringa oleifera leaf extract was determined using ultra-high performance liquid chromatography equipped with a PDA and coupled with electrospray ionization quadrupoletime-of-flight mass spectrometry (UHPLC-ESI-qTOFMS, Micromass) from Agilent Technologies. A column BEH-C18 $2.1 \times 100 \mathrm{~mm}, 1.7 \mu \mathrm{m}$, (Waters, Milford, MA, USA) was used. The mobile phase employed was made of solvent A (water-formic acid: 99.9:0.1, v/v) and 
solvent B (acetonitrile-formic acid: 99.9:0.1, v/v), using the following gradient profile: $5 \% \mathrm{~B}$ at $0 \mathrm{~min}, 40 \% \mathrm{~B}$ at 8 min, reaching $95 \% \mathrm{~B}$ at $9 \mathrm{~min}$, held constant at $95 \% \mathrm{~B}$ over 9-10 min and returning to the initial conditions at $10.5 \mathrm{~min}$. The injection volume was $5 \mu \mathrm{L}$ and the flow rate was $0.25 \mathrm{~mL} / \mathrm{min}$. Mass spectrometry data were acquired by electrospray ionization in the positive ionization mode. The full scan mass covered the range from $\mathrm{m} / \mathrm{z} 100$ to $\mathrm{m} / \mathrm{z} 1200$. The ionization parameters were: capillary voltage $3200 \mathrm{~V}$, sample cone voltage of $30 \mathrm{~V}$, source temperature of $80^{\circ} \mathrm{C}$, desolvation temperature of $220^{\circ} \mathrm{C}$, cone gas flow of $50 \mathrm{~L} / \mathrm{h}$ and desolvation gas flow of $400 \mathrm{~L} / \mathrm{h}$. High purity nitrogen was used as desolvation gas, cone - and collision gas (Ncube et al. 2014).

\section{Statistical analysis}

All determinations were carried out in three replicates. The results were expressed as Mean $\pm \mathrm{SD}$. The means were compared using analysis of variance (ANOVA) and separated using Duncan's multiple-range tests, and $p<$ 0.05 was regarded as significant. RSM in Stat graphic (Stat graphic Centurion XV, Virginia, USA), was used to fit data into second order polynomial models. The validated second-order polynomial models were used in Minitab 16 software to generate contour plots necessary for the determination of optimal area. Principal Component Analysis (PCA) was carried out using XL-STAT Software (XLSTAT 2007, Addinsoft, New York).

\section{Results and discussion}

The effects of time and temperature of steam blanching, roasting, fermentation/ oxidation and drying on antioxidant activity (DPPH scavenging activity and TAC) in Moringa oleifera leaves were investigated at 5 levels of temperature and 3 levels of time, for a total of 9 experimental points per treatment. The measured AOA at all experimental points is given in Table 3.

\section{Modelling and optimization}

The experimental data was analyzed and second order polynomial models were generated to predict the dependent variables (TAC and DPPH scavenging activity) from coded levels of the studied factors (temperature and time) in every post-harvest treatment. These models are useful in predicting the behavior of each dependent variable as a function of independent process parameters considered in the study (Myers \& Montgomery 2002).

To verify the adequacy and ensure that the selected second order polynomial models adequately fit the obtained AOA into the studied range, the models were statistically tested for every validation parameter, namely the lack-of-fit, the coefficient of determination $\left(R^{2}\right)$, the absolute average deviation (AAD), the bias (Bf) and accuracy (Af) factors. The $p$ value of the lack-of-fit was significant $(p<0.05)$ for most models except the TAC of dried leaf extract, thus demonstrating their adequacy to predict the dependent variable in the experimental domain. The coefficient of determination ranged from 0.77 to 0.99 , meaning that 77 to $99 \%$ of the total variation could be explained by the defined models. These acceptable values of the coefficient of determination suggest an overall good performance of the models. Likewise, the AAD ranged between $0.00-0.04$, indicating a negligible deviation between experimental and fitted models, in accordance with the coefficient of determination. This observation was supported by the values for accuracy and bias factors which were all close to 1 as required for accurate models. Hence, it is clear that all tested parameters were close to their reference values. This is an indication that the fitted models were highly significant $(p<0.05)$ for all responses. The overall evaluation of these parameters show that selected polynomial models are valid and adequately fit TAC and DPPH activity to temperature and time in the experimental domain considered for every post-harvest treatment.

Regression coefficients for the intercept, linear, quadratic and interaction terms of the model were analyzed statistically for variation using ANOVA (Table 4). The relationship between the process conditions (time and temperature) in every treatment and antioxidant activity is depicted in Eqs. 5-12 and illustrated in Fig. 1. Optimal conditions which represent the area where both DPPH scavenging activity and TAC are maximal for each treatment were selected and hatched (Fig. 1).

\section{Modelling and optimizing steam blanching of Moringa leaves}

The variation of TAC and DPPH activity during steam blanching of Moringa oleifera leaves are given by Eqs. 5 and 6 respectively.

TAC $(\mathrm{g} \mathrm{AAE} / 100 \mathrm{~g})=7.69+0.33 \mathrm{X}_{1}-0.09 \mathrm{X}_{2}-0.27 \mathrm{X}_{1}^{2}-0.91 \mathrm{X}_{1} \mathrm{X}_{2}-0.25 \mathrm{X}_{2}^{2}$

$$
\begin{aligned}
\mathrm{DPPH}(\mathrm{mg} \text { AAE } / 100 \mathrm{~g})= & 559.2+32.2 \mathrm{X}_{1} \\
& +8.2 \mathrm{X}_{2}-56 \mathrm{X}_{1}^{2} \\
& +4.2 \mathrm{X}_{1} \mathrm{X}_{2}+16 \mathrm{X}_{2}^{2}
\end{aligned}
$$

From regression coefficients associated to independent parameters in Eqs. 5 and 6 , it is apparent that temperature $\left(\mathrm{X}_{1}\right)$ had the most significant $(p<0.05$, Table 4) and positive linear effect on both DPPH scavenging activity and TAC whereas time $\left(\mathrm{X}_{2}\right)$ showed the least influencing and non-significant $(p>0.05$, Table 4$)$ linear effect on both responses. Thus, both the DPPH scavenging activity and TAC increased with increase in 
Table 3 Antioxidant properties of steam-blanched, fermented/oxidised, dried and roasted Moringa leaf extracts

\begin{tabular}{|c|c|c|c|c|c|c|c|c|}
\hline \multirow[b]{2}{*}{ Runs } & \multicolumn{2}{|c|}{ Steam blanching } & \multicolumn{2}{|c|}{ Fermentation/Oxidation } & \multicolumn{2}{|l|}{ Drying } & \multicolumn{2}{|l|}{ Roasting } \\
\hline & TAC & DPPH & TAC & DPPH & TAC & DPPH & TAC & DPPH \\
\hline 1 & $7.58 \pm 0.59$ & $565 \pm 13$ & $7.40 \pm 0.34$ & $664 \pm 7$ & $5.71 \pm 0.04$ & $644 \pm 16$ & $5.86 \pm 0.17$ & $710 \pm 7$ \\
\hline 2 & $7.74 \pm 0.64$ & $560 \pm 24$ & $7.46 \pm 0.12$ & $656 \pm 4$ & $5.72 \pm 0.02$ & $651 \pm 6$ & $5.63 \pm 0.09$ & $694 \pm 2$ \\
\hline 3 & $7.75 \pm 0.23$ & $552 \pm 13$ & $7.99 \pm 0.14$ & $669 \pm 1$ & $5.63 \pm 0.50$ & $656 \pm 1$ & $5.98 \pm 0.10$ & $706 \pm 1$ \\
\hline 4 & $7.64 \pm 0.28$ & $541 \pm 9$ & $6.72 \pm 0.61$ & $651 \pm 12$ & $6.48 \pm 0.14$ & $646 \pm 12$ & $5.38 \pm 0.17$ & $649 \pm 1$ \\
\hline 5 & $7.19 \pm 0.42$ & $465 \pm 5$ & $7.84 \pm 0.92$ & $691 \pm 9$ & $7.32 \pm 0.50$ & $593 \pm 5$ & $7.07 \pm 0.20$ & $731 \pm 3$ \\
\hline 6 & $7.24 \pm 0.37$ & $576 \pm 10$ & $7.15 \pm 0.35$ & $551 \pm 15$ & $6.53 \pm 0.12$ & $660 \pm 4$ & $6.52 \pm 0.26$ & $729 \pm 1$ \\
\hline 7 & $8.19 \pm 0.63$ & $558 \pm 2$ & $8.98 \pm 0.96$ & $664 \pm 7$ & $6.19 \pm 0.19$ & $638 \pm 13$ & $6.44 \pm 0.15$ & $725 \pm 1$ \\
\hline 8 & $6.82 \pm 0.39$ & $542 \pm 16$ & $8.19 \pm 0.51$ & $676 \pm 2$ & $6.31 \pm 0.24$ & $622 \pm 8$ & $5.99 \pm 0.06$ & $730 \pm 5$ \\
\hline 9 & $7.46 \pm 0.33$ & $552 \pm 29$ & $7.16 \pm 0.31$ & $595 \pm 11$ & $6.39 \pm 0.01$ & $639 \pm 5$ & $6.92 \pm 0.19$ & $735 \pm 6$ \\
\hline
\end{tabular}

TAC (g AAE/100 g DM); DPPH (mg AAE/100 g DM)

blanching temperature. In addition, TAC was significantly influenced by the interaction between blanching time and temperature whereas DPPH scavenging activity was significantly $(p<0.05$, Table 4$)$ affected by the quadratic effect of temperature.

Irrespective of blanching time, DPPH scavenging activity increased with temperature up to a maximum at $90-95^{\circ} \mathrm{C}$ and thereafter decreased. On the other hand, TAC increased with increasing temperature and time up to a maximum at $90-100^{\circ} \mathrm{C}$ for a time lower than $11 \mathrm{~min}$ (Fig. 1a). Significantly higher values of TAC and DPPH scavenging activity were observed in the temperature range of $90-$ $100{ }^{\circ} \mathrm{C}$ and $90-95^{\circ} \mathrm{C}$ respectively. Hence, the compromise that simultaneously involves higher TAC and DPPH scavenging activity was obtained when Moringa leaves were steam blanched at $92-96^{\circ} \mathrm{C}$ for 5 to $10 \mathrm{~min}$ (Fig. 1a).

\section{Modelling and optimizing fermentation/oxidation of Moringa leaves}

The effect of temperature and time of oxidation on both TAC and DPPH are represented in Eqs. 7 and 8.

$$
\begin{aligned}
\operatorname{TAC}(\mathrm{g} \mathrm{AAE} / 100 \mathrm{~g})= & 6.70-0.72 \mathrm{X}_{1}-0.21 \mathrm{X}_{2} \\
& +0.39 \mathrm{X}_{1}^{2}-0.40 \mathrm{X}_{2} \mathrm{X}_{1}-0.29 \mathrm{X}_{2}^{2}
\end{aligned}
$$

$\mathrm{DPPH}(\mathrm{mg} \mathrm{AAE} / 100 \mathrm{~g})=663.4-56.1 \mathrm{X}_{1}-23 \mathrm{X}_{2}-58.1 \mathrm{X}_{1}^{2}-18.2 \mathrm{X}_{2} \mathrm{X}_{1}+7.8 \mathrm{X}_{2}^{2}$

DPPH scavenging activity of fermented/oxidized leaves was negatively (Eqs. 7,8$)$ and significantly $(p<0.05$, Table 4) affected by the linear effects of time and temperature, whereas TAC was only significantly $(p<$ 0.05 , Table 4) affected by the linear effect of temperature. Temperature had a greater effect on these variables compared to time. These negative coefficients indicate that both DPPH and TAC decrease with an increase in fermentation/oxidation time and temperature as illustrated in Fig. 1b. Maximal values for TAC were obtained at temperatures lower than $30^{\circ} \mathrm{C}$, whereas for DPPH scavenging activity maximal values were observed with Moringa leaves fermented at $25-35^{\circ} \mathrm{C}$ for 15 to 35 min (Fig. 1b). Thus, the area represented by temperature between 25 and $30^{\circ} \mathrm{C}$ and oxidation time of $15-35 \mathrm{~min}$ was found to be optimum (Fig. 1b) for TAC and DPPH.

\section{Modelling and optimizing drying of Moringa leaves}

To depict the mathematical relationship between the temperature and the time of drying on both TAC and DPPH scavenging activity, the experimental data were fitted into second order polynomial Eqs. 9 and 10.

Table 4 ANOVA test ( $P$-value) of time and temperature of steam blanching, fermentation/Oxidation, drying and roasting on AOA in

\begin{tabular}{|c|c|c|c|c|c|c|c|c|}
\hline & \multicolumn{2}{|c|}{ Steam blanching } & \multicolumn{2}{|c|}{ Fermentation/Oxidation } & \multicolumn{2}{|c|}{ Drying } & \multicolumn{2}{|c|}{ Roasting } \\
\hline & TAC & DPPH & TAC & DPPH & TAC & DPPH & TAC & DPPH \\
\hline$X_{1}$ & $0.02^{a}$ & $0.015^{\mathrm{a}}$ & $0.04^{a}$ & $0.005^{\mathrm{a}}$ & $0.01^{a}$ & $0.02^{\mathrm{a}}$ & $0.03^{a}$ & $0.02^{a}$ \\
\hline$x_{2}$ & 0.24 & 0.18 & 0.32 & $0.03^{a}$ & $0.05^{a}$ & $0.09^{b}$ & $0.10^{\mathrm{b}}$ & 0.63 \\
\hline$X_{1}^{2}$ & $0.08^{b}$ & $0.012^{\mathrm{a}}$ & 0.26 & $0.01^{\mathrm{a}}$ & $0.00^{\mathrm{a}}$ & $0.03^{\mathrm{a}}$ & 0.12 & 0.23 \\
\hline$x_{1} x_{2}$ & $0.01^{a}$ & 0.65 & 0.34 & 0.15 & $0.10^{b}$ & 0.75 & 0.13 & 0.92 \\
\hline$X_{2}^{2}$ & $0.09^{b}$ & 0.13 & 0.37 & 0.34 & $0.00^{\mathrm{a}}$ & 0.53 & $0.04^{a}$ & $0.03^{\mathrm{a}}$ \\
\hline
\end{tabular}
M. oleifera leaf extracts

$\mathrm{X}_{1}$ : Temperature, $\mathrm{X}_{2}$ : Time; ${ }^{\mathrm{a}}$ significant at $95 \%{ }^{\mathrm{b}}{ }^{\mathrm{significant}}$ at $90 \%$ confidence level 

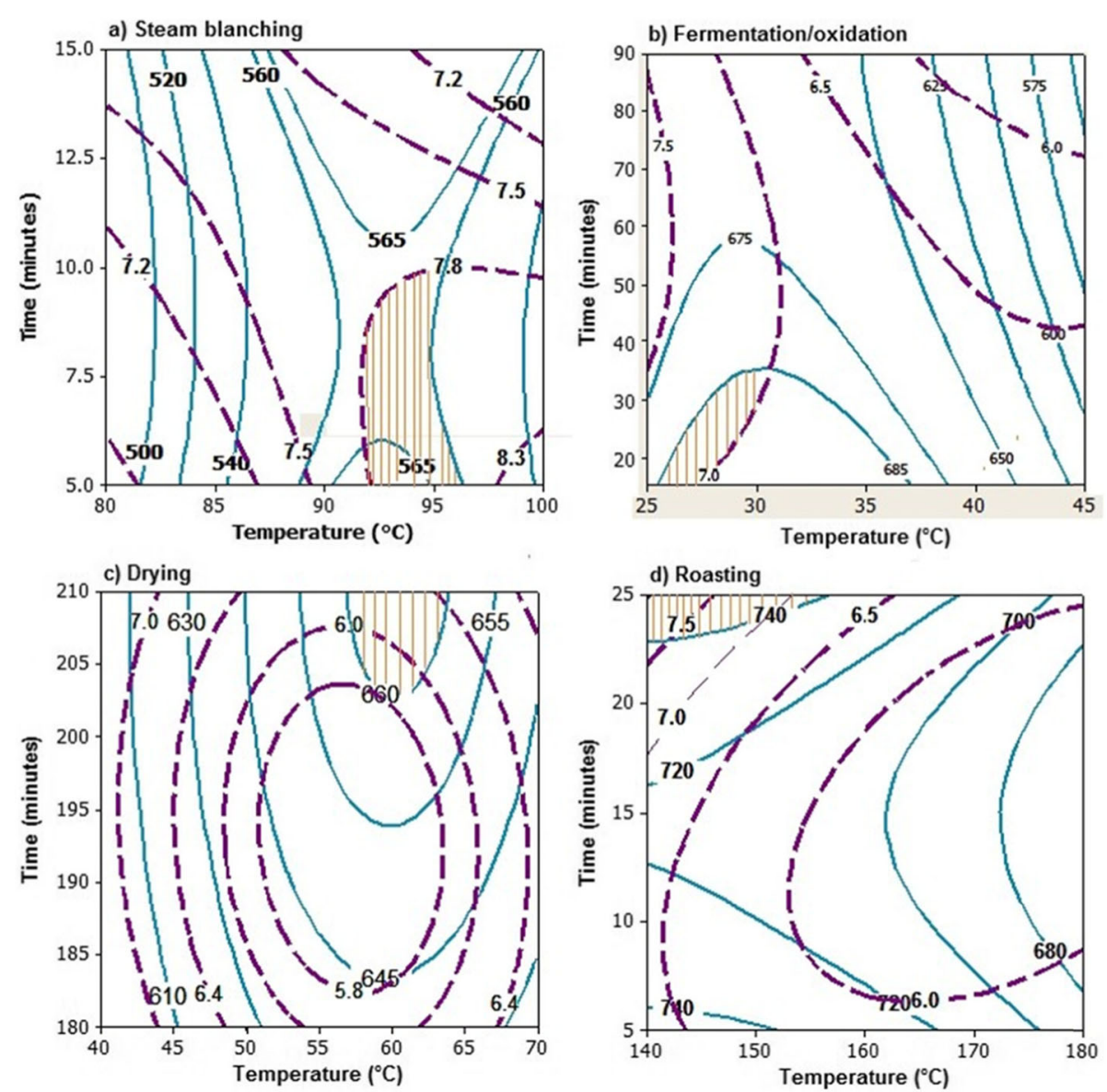

Fig. 1 Contour plots of the influence of temperature and time on TAC and DPPH scavenging activity for a Steam Blanched, $\mathbf{b}$ Fermented/ Oxidized, c Dried and d Roasted Moringa oleifera leaves. (Total Antioxidant Capacity (broken line); DPPH scavenging activity (solid line))

$$
\begin{aligned}
\operatorname{TAC}(\mathrm{g} \mathrm{AAE} / 100 \mathrm{~g})= & 5.69-0.27 \mathrm{X}_{1}+0.12 \mathrm{X}_{2} \\
& +1.21 \mathrm{X}_{1}^{2}+0.15 \mathrm{X}_{1} \mathrm{X}_{2} \\
& +0.48 \mathrm{X}_{2}^{2}
\end{aligned}
$$

$$
\begin{aligned}
\mathrm{DPPH} & (\mathrm{mg} \mathrm{AAE} / 100 \mathrm{~g}) \\
= & 650.8+23.8 \mathrm{X}_{1}+11.3 \mathrm{X}_{2}-31.4 \mathrm{X}_{1}^{2} \\
& +2.6 \mathrm{X}_{1} \mathrm{X}_{2}-4.3 \mathrm{X}_{2}^{2}
\end{aligned}
$$

The regression coefficients associated to the process parameters showed that both drying temperature and time had a positive influence on DPPH scavenging activity. On the other hand, drying temperature and duration had respectively an overall negative and positive effect on TAC; suggesting that drying Moringa leaves at low temperatures for longer duration could be beneficial in preserving maximum TAC. DPPH scavenging activity of dried Moringa leaves was significantly $(p<0.05) \quad$ influenced by drying temperature, whereas, both linear and quadratic effect of temperature and time had significant $(p<0.05)$ effect on TAC (Table 4).
From Fig. 1c we observe that DPPH scavenging activity of Moringa oleifera leaves increases with increasing temperature and time of drying, reaching a maximum at temperature of $58-63^{\circ} \mathrm{C}$ and time of $203-210 \mathrm{~min}$. Concerning TAC, optimal values were obtained in the drying range of $50-65^{\circ} \mathrm{C}$ for $200 \mathrm{~min}$ and above. Thus, the optimal area for drying Moringa leaves was selected as 58$63^{\circ} \mathrm{C}$ for $203-210 \mathrm{~min}$ in consideration of higher DPPH scavenging activity (Fig. 1c).

\section{Modelling and optimizing roasting of Moringa leaves}

The mathematical models showing the relationship between roasting temperature and time on both TAC and DPPH scavenging activity are depicted in Eqs. 11 and 12 .

$$
\begin{aligned}
\operatorname{TAC}(\mathrm{g} \mathrm{AAE} / 100 \mathrm{~g})= & 5.83-0.55 \mathrm{X}_{1} \\
& +0.29 \mathrm{X}_{2} \\
& +0.40 \mathrm{X}_{1}^{2}-0.49 \mathrm{X}_{1} \mathrm{X}_{2} \\
& +0.72 \mathrm{X}_{2}^{2}
\end{aligned}
$$




$$
\begin{aligned}
\mathrm{DPPH} & (\mathrm{mg} \mathrm{AAE} / 100 \mathrm{~g}) \\
= & 703-29 \mathrm{X}_{1}+2.7 \mathrm{X}_{2}-13 \mathrm{X}_{1}^{2}-1 \mathrm{X}_{1} \mathrm{X}_{2} \\
& +40 \mathrm{X}_{2}^{2}
\end{aligned}
$$

Both TAC and DPPH scavenging activity were significantly $(p<0.05)$ negatively affected by the roasting temperature, whereas, roasting time had positive but non-significant $(p>0.05)$ effect on both responses (Eqs. 11 and 12, Table 4). That is, both DPPH scavenging activity and TAC of roasted M. oleifera leaves decreased with an increase in roasting temperature whereas they increased with roasting time (Fig. 1d). Thus, roasting at lower temperatures for longer periods is favorable for antioxidant activity in Moringa leaves. Maximum TAC and DPPH scavenging activity in roasted Moringa oleifera leaves were observed for roasting temperature range of $140-150^{\circ} \mathrm{C}$ and roasting duration of $23-25 \mathrm{~min}$. Consequently, roasting of $M$. oleifera leaves at $140-150{ }^{\circ} \mathrm{C}$ for 23-25 min presents a compromise because both TAC and DPPH scavenging activity are simultaneously maximum in these conditions (Fig. 1d).

\section{Verification of models in the optimal area}

The verification experiments were performed at the predicted optimum conditions obtained from analysis of RSM plots. The experimental values were reasonably close to the predicted values confirming the validity and suitability of the predicted models for estimating the responses (Table 5).

\section{Comparative analysis of the impact of post-harvest} treatments on phenolic content, antioxidant activity and phenolic profile of Moringa oleifera leaves

In order to identify the most appropriate post harvest treatment for the improvement of AOA in $M$. oleifera leaves, fresh leaves were processed under the determined optimal conditions (Table 5) and their phenolic content, phenolic profile and AOA determined and compared.

\section{Impact of post-harvest treatments on phenolic content and antioxidant activity of Moringa oleifera leaves}

Total phenolic content in treated Moringa leaf extracts ranged between $81.7-155.8 \mathrm{mgGAE} / \mathrm{g}$ of extract respectively for steam blanched and roasted leaves (Fig. 2).
These values for TPC are in accordance with that reported for aqueous extracts of dried Moringa leaves 105 mg GAE/g extract (Singh et al. 2009) and fresh Moringa leaves $120 \mathrm{mg} \mathrm{GAE} / \mathrm{g}$ extract (Jaiswal et al. 2013). On the other hand, Verma et al. (2009) obtained high concentrations of TPC ( $250 \mathrm{mg}$ GAE/g extract) in acidified $(1 \% 6 \mathrm{~N} \mathrm{HCl}) 50 \%$ methanolic extract of dried leaves, while Chumark et al. (2008) reported low total phenolic content of $20.5 \mathrm{mg} \mathrm{GAE} / \mathrm{g}$ in aqueous extract of fresh leaves. These results show the variability in TPC with processing treatment and extraction conditions.

Drying and fermentation/oxidation of fresh Moringa leaves had no significant $(p>0.05)$ impact on their total phenolic content (Fig. 2). Ng et al. (2021) observed that fermented C. sinensis and Peperomia pellucida herbal tea samples displayed lowest TPC content compared to their non-fermented counterparts. Indeed, the behavior of phenolic compounds during fermentation/oxidation of plants material is based on different mechanisms. Firstly, fermentation/oxidation may cause the loss of hydroxyl groups in polyphenols and the formation of secondary aromatic or color compounds (Barek et al. 2015). On the other hand, fermentation/oxidation induces the formation of polymeric tannin from phenolic acid monomer (Moodley et al. 2015) or the formation of flavonoid derivatives from the recombination of heterocyclic aglycone phenolic compounds (Ng \& See 2019).

Steam blanching on its part led to a significant reduction (31\%) in total phenolic content of fresh Moringa leaves. Although blanching food matrix induces partial inactivation of peroxidases (POX) that could be beneficial for polyphenols preservation, it also causes breakdown of the phenolic ring (Gonçalves et al. 2010). Moreover, blanching may cause heat-induced softening of food matrix, leading potentially to enhanced solubilisation and leaching out of phenolic compounds (Palermo et al. 2013). Thus, blanching could favour the leaching of phenolic compounds which in part explains the observed reduction in TPC of blanched Moringa leaves. Similarly, Potisate et al. (2014) reported a reduction in kaempferol and quercetin content following steam blanching of Moringa leaves. Similar effects have been reported with other vegetables where steam

\begin{tabular}{|c|c|c|c|c|c|c|}
\hline \multirow[t]{2}{*}{ Treatments } & \multicolumn{2}{|c|}{ Selected optimal points } & \multicolumn{2}{|c|}{ TAC (g AAE/100 g DM) } & \multicolumn{2}{|c|}{ DPPH (mg AAE/100 g DM) } \\
\hline & $\mathrm{T}\left({ }^{\circ} \mathrm{C}\right)$ & $\mathrm{t}$ (minutes) & Fitted & Experimental & Fitted & Experimental \\
\hline Steam blanching & 92 & 6 & 7.8 & $6.6 \pm 0.4$ & 566.4 & $567 \pm 1$ \\
\hline Fermentation/Oxidation & 30 & 30 & 7.0 & $7.3 \pm 0.5$ & 711.5 & $713 \pm 2$ \\
\hline Drying & 60 & 210 & 6.4 & $6.0 \pm 0.2$ & 663.1 & $663 \pm 2$ \\
\hline Roasting & 145 & 25 & 7.8 & $7.7 \pm 0.2$ & 760.9 & $758 \pm 3$ \\
\hline
\end{tabular}
blanching caused significant losses in flavonoids,

Table 5 Fitted and experimental responses at selected optimal points

$T$ Temperature, $t$ Time 


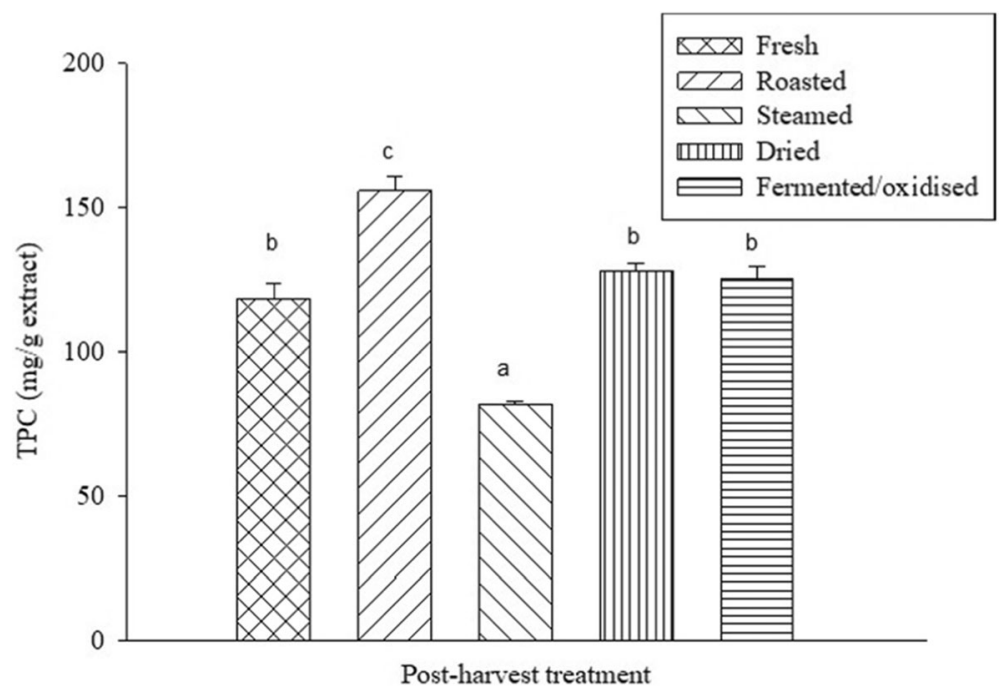

Fig. 2 Total phenolic content in fresh and processed leaf extracts of Moringa oleifera

phenolic acids, TRAP and FRAP in broccoli (Pellegrini et al. 2010) and of phenolic compounds in Adansonia digitata leaves (Irondi et al. 2016) and Amanranthus species (Amin et al. 2006).

Roasting was the only treatment that significantly $(p<$ $0.05)$ improved (43\%) total phenolic content of $M$ oleifera leaves compared to the fresh untreated leaves (Fig. 2). Improvement of phenolic content with roasting could be ascribed to the inactivation of enzymes such as polyphenol oxidases (PPO) and peroxidases (POX) in Moringa leaves. PPO catalyze the transformation of polyphenols into o-quinones whereas POX catalyze oxidation of polyphenols (Zhang \& Shao 2016); which could lead to their degradation. Roasting may cause total inactivation of these enzymes and thus prevent enzymatic degradation of phenolic compounds, thereby preserving them. Thus, higher phenolic content in roasted leaf extract could be the result of effective conversion of bound insoluble phenolic compounds to soluble forms that are easily extracted (Jeong et al. 2004; Yu et al. 2005) or thermal destruction of cell walls and sub-cellular compartments that favors the release of bound phenolic compounds (Juániz et al. 2016). In plant materials, a number of phenolic compounds are linked to various cell wall components such as carbohydrates and proteins. Their destruction therefore will lead to release of these compounds. Higher total phenolic content has previously been reported in roasted Moringa leaves (Parwani et al. 2016). In this regard, Parwani et al. (2016) observed that roasting Moringa leaves at $150^{\circ} \mathrm{C}$ for $5 \mathrm{~min}$ led to a $14 \%$ increase in TPC. These authors suggested that increase in TPC could be due to the liberation of insoluble and bound phenolic compounds from their complexes in the cell wall under thermal conditions.
Figure $3 \mathrm{a}$ and $\mathrm{b}$ present respectively DPPH and ABTS scavenging activity of treated Moringa leaf extracts. A dose-response relationship was found in DPPH and ABTS radical scavenging activity of all samples regardless of the post-harvest treatment applied. Overall, the roasted leaf extract exhibited a higher radical scavenging activity (22-31\%) compared to the fresh leaf extract and the other treatments, indicating that antioxidant activity in Moringa oleifera leaves is enhanced by the roasting process. This suggests that roasted Moringa leaves does not only have higher phenolic content but that they are endowed with potent AOA as well. Improvement of AOA with roasting in Moringa leaves has been reported by Parwani et al. (2016).

The enhancement observed in AOA with roasting could be ascribed to one or a combination of several factors such as; the increase in phenolic content observed in roasted compared to fresh leaf extract, the formation of Maillard reaction products during the roasting process and the conversion of parent phenolic compounds into polyphenolic analogues having higher antioxidant activity. In fact, $\mathrm{AOA}$ is generally attributed to phenolic content in Moringa leaves (Nobossé et al., 2017; Rodríguez-Pérez et al. 2015). On the other hand, it has been demonstrated that heating phenolic compounds, namely glycosides such as rutin, in the presence of an amino acid like lysine results in the formation of Maillard reaction products endowed with higher AOA compared to native glycosides (Zhang et al. 2016). Moringa leaves contain both glycosides and amino acids that could come in contact upon cell breakdown during the roasting process. Furthermore, it has been observed that during roasting, phenolic acids such as caffeic acid are polymerized into newly formed compounds that exhibit 

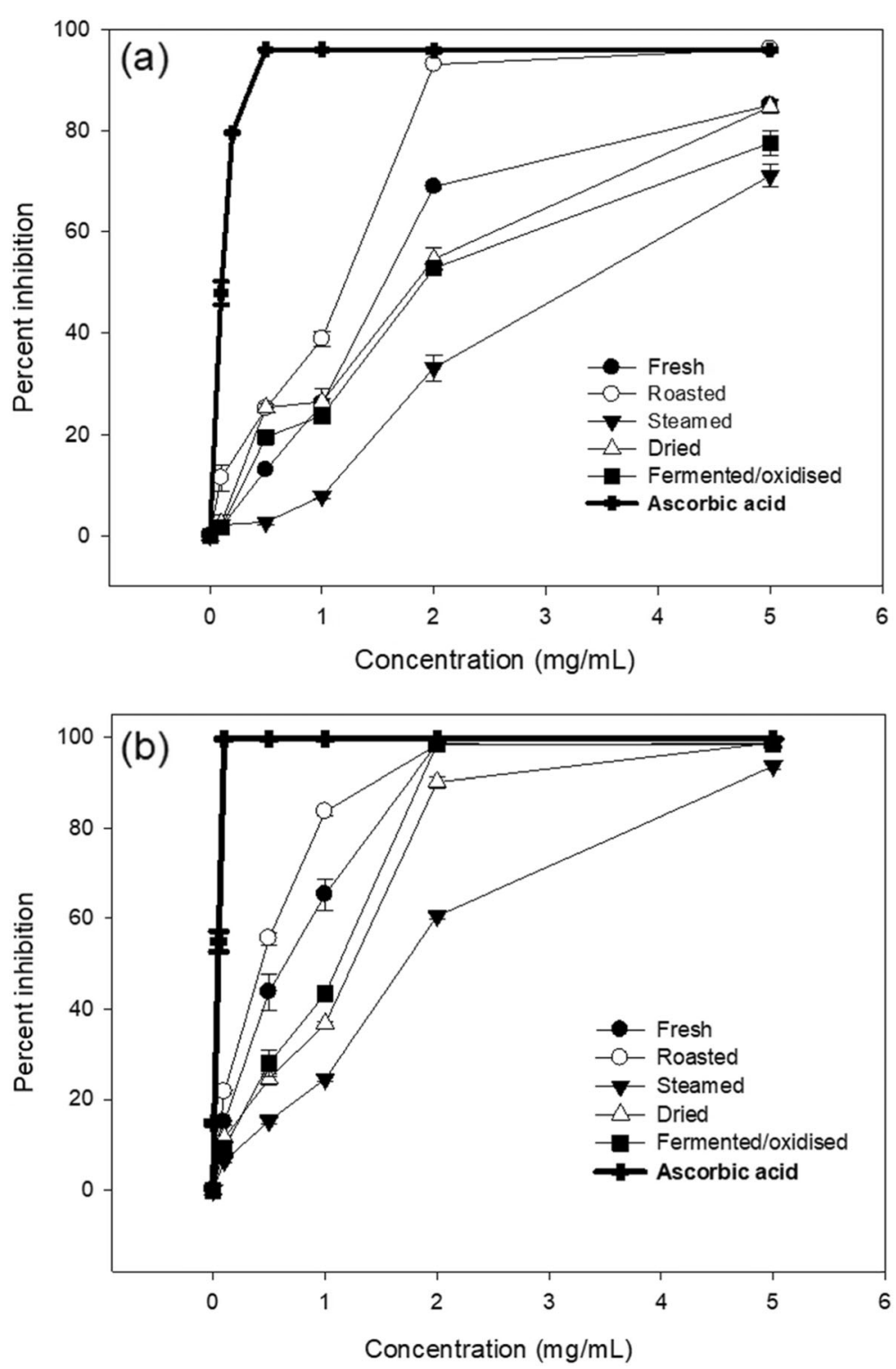

Fig. 3 Free radical scavenging activity in fresh and processed leaf extracts of Moringa oleifera. a DPPH scavenging activity; b ABTS scavenging activity

stronger AOA than native polyphenols (Chen et al. 1999).

To gain further insight into the effects of processing treatments on the radical scavenging activity of Moringa leaf extracts the $50 \%$ inhibition concentration $\left(\mathrm{IC}_{50}\right)$, which represents the concentration of extract necessary to scavenge $50 \%$ of $\mathrm{DPPH}^{*}$ or $\mathrm{ABTS}^{+}$radicals was determined. The $\mathrm{IC}_{50}$ value is inversely proportional to the antioxidant activity of extracts. In accordance with the values of $\mathrm{IC}_{50}$ recorded on Table 6 , the radical scavenging activity is most important in roasted leaf extract followed by fresh leaves, confirming the fact that roasting of fresh Moringa leaves is the post-harvest treatment that best improves antioxidant potential. Extracts from oxidized, dried and steam blanched leaves exhibited significantly $(p<0.05)$ lower ABTS and DPPH scavenging activity compared to the fresh leaf extract (Table 6); indicating that these treatments have an overall negative impact on the radical scavenging activity of $M$. oleifera leaves with steam blanching having the most damaging effect. Reduction of radical scavenging activity may be due to losses or degradation of certain types of phenolic compounds or other free radical-scavenger components during treatment (Amin et al. 2006).

All post-harvest treatments significantly $(p<0.05)$ and negatively influenced FRAP (Fig. 4a). Oxidized leaf extract had the lowest reducing capacity. TAC on its part, was significantly $(p<0.05)$ highest in roasted leaf extract 
and lowest in both steam blanched and dried samples compared to fresh leaf extract (Fig. 4b). Fermentation/ Oxidation caused no significant change $(p>0.05)$ in TAC of Moringa leaf extract. Previously it was shown that FRAP and DPPH radical scavenging activity in both C. sinensis and $P$. pellucida tea are inversely correlated to the degree of fermentation/oxidation ( $\mathrm{Ng}$ et al. 2021). It has been suggested that degradation of antioxidant compounds such as ascorbic acid, chlorophyll and saponins could be responsible for the low antioxidant activities in fermented/oxidized vegetables (Barek et al. 2015).

Reduction in antioxidant activity with blanching could be attributed to the losses in phenolic compounds observed during steam-blanching. Important losses in antioxidant activity including DPPH scavenging activity and FRAP have been reported in Irish York cabbage (Jaiswal et al. 2012), Amarantus cruentus and Vernonia amygdalina (Oboh 2005); as well as TRAP and FRAP in broccoli (Pellegrini et al. 2010) following hot water blanching. However, some authors have reported an overall enhancement of antioxidant activity after blanching of several tropical leafy vegetables including Amaranthus hybridus, Ipomea batata leaves (Adefegha \& Oboh, 2011) and Brassica sp. (Pellegrini et al. 2010). It is worth noting that in most cases, enhancement of antioxidant activity was accompanied by a decrease in total phenolic content (Miglio et al. 2008; Pellegrini et al. 2010) while in other cases, improvement of TPC was accompanied by decrease of antioxidant activity (Oboh 2005). These observations highlight the variation in antioxidant potential of different phenolic compounds as well as the contribution of compounds other than polyphenols such as chlorophyll (Nobossé et al. 2018) and carotenoids (Nobossé et al. 2017) to antioxidant activity in blanched leaves.

\section{Correlation between post-harvest treatments and antioxidant potential of Moringa leaf extracts}

Principal Component Analysis (PCA) was applied to evaluate the influence of processing treatments on antioxidant activity and phenolic compounds of Moringa leaf extracts. Eigen analysis of the principal components revealed that PC1 was mainly characterized by TAC, $\mathrm{DPPH}$, and ABTS; PC2 was contributed to by TFC and FRAP; TAC and TPC contributed to PC3 while TFC and FRAP were the main contributing factor for PC4. The first principal component had the highest eigenvalue of 4.2 and accounted for $70.7 \%$ of the variability in the data set. The second principal component had eigenvalue of 1.4 and accounted for $23.3 \%$ of the variance in the data while PC3 and PC4 had eigenvalues lower than 1 and accounted respectively for 4.6 and $1.2 \%$ of the variance. Therefore, both PC1 and PC2 together accounted for $94.1 \%$ of the total variance in the data set and were considered significant descriptors of data variance based on their eigenvalues higher than 1.0 according to Kaiser's rule (Shin et al. 2010).

Figure 5 shows the bi-dimensional representation of all the antioxidants, phenolic compounds and processing method of Moringa leaf extracts according to the two selected Principal Components (PC). Fresh and roasted leaf extracts which are characterized by higher phenolic content and antioxidant capacity are represented on the right side of the graphic. On the left side are the dried, fermented and blanched Moringa leaf extracts characterized by lower phenolic content and antioxidant capacity. These results show that AOA is directly correlated with phenolic content and is supported by the significant $(p<$ $0.05)$ positive correlation observed between phenolic content and antioxidant capacity measured by DPPH $(r=0.93)$, ABTS $(r=0.76)$ and TAC $(r=0.69)$.

\section{LC-ESI-MS/QTOF identification of phenolic compounds in Moringa leaves}

Figure 6a-e, presents chromatograms of the phenolic profiles of fresh and processed leaf extracts. Overall, 19 different peaks could be visible on the chromatograms out of which 12 were successfully identified, based on their retention time and molecular mass, and also by comparing them with standard polyphenols. Both fresh and roasted leaf extracts each showed a total of 17, but not similar peaks. Roasting led to the formation of two new compounds (peaks 11 and 13, both of which were identified as Quercetin-3-O-acetyl glucoside and Kaempferol-3-o-acetylglucoside respectively); but also caused the disappearance of two parent compounds (peaks 14 corresponding to Quercetin-3-O-rhamnoside and 16 corresponding to an unidentified compound). Fermented/oxidized and dried leaves had 12 peaks each, whereas blanching saw a disappearance of most of the peaks observed in the fresh leaves with just 9 of them visible. Compound 14 identified as quercetin-3-O-rhamnoside was present only in fresh extract. Aside from roasting treatment that led to an increase in the number of peaks and an increase in the intensity of some, the

Table $6 I C_{50}$ values of Moringa oleifera extracts on DPPH and ABTS scavenging activities

\begin{tabular}{|c|c|c|c|c|c|c|}
\hline & Fresh & Roasted & Dried & Fermented/Oxidised & Steamed & $\mathrm{AA}$ \\
\hline $\mathrm{DPPH}\left(\mathrm{IC}_{50}, \mathrm{mg} / \mathrm{mL}\right)$ & 1.55 & 1.20 & 1.84 & 1.91 & 3.34 & 0.10 \\
\hline ABTS $\left(I C_{50}, \mathrm{mg} / \mathrm{mL}\right)$ & $0.63)$ & 0.43 & 1.24 & 1.10 & 1.70 & 0.05 \\
\hline
\end{tabular}




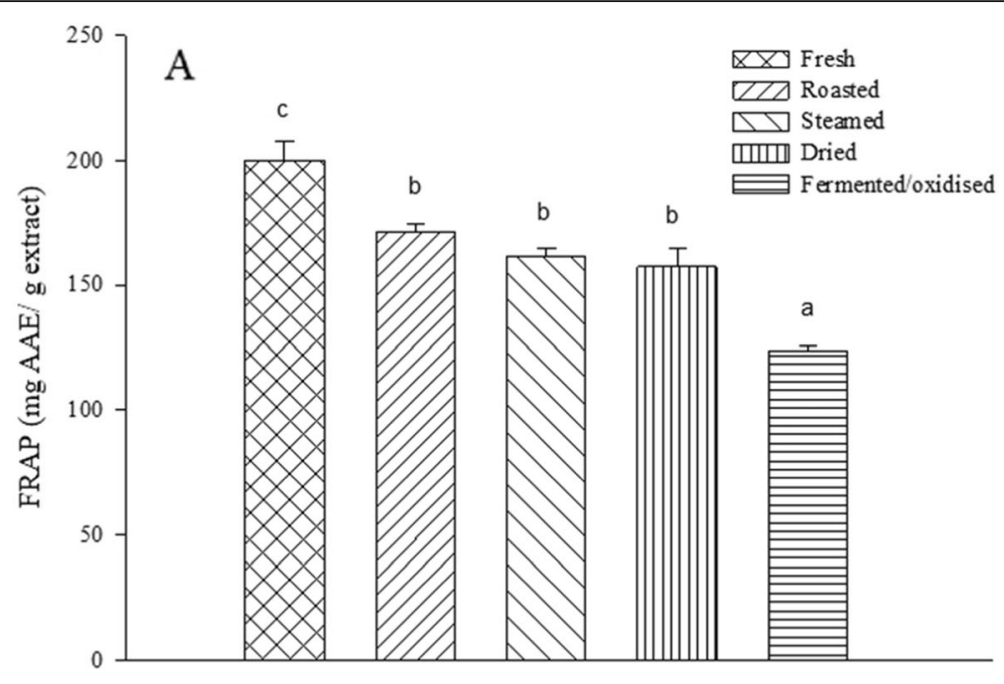

Post-harvest treatment

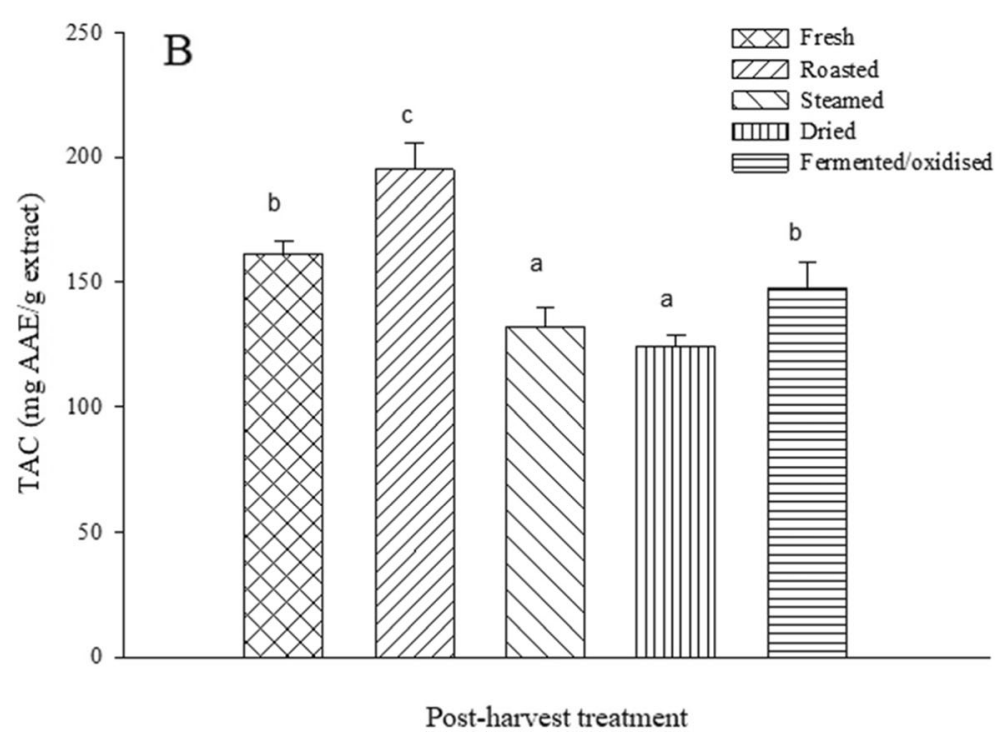

Fig. 4 Reducing capacity of fresh and processed Moringa oleifera leaf extracts. (A) Ferric Reducing Antioxidant Power (FRAP); (B) Total antioxidant capacity (TAC)

other 3 treatments (drying, fermentation/oxidation, blanching) engendered reductions in the number and also the intensity of some of the peaks.

The presence of quercetin-3-O-(acetyl) glucoside had previously been reported in dried Moringa leaf extract from various origins (Karthivashan et al. 2013; Nouman et al. 2016). Some phenolic acids such as caffeic acid, chlorogenic acid and flavonoids such as quercetin, kaempferol and apigenin were previously detected in Moringa leaf extracts (Karthivashan et al. 2013; Makita et al. 2016; Nouman et al. 2016; Vongsak et al. 2013). Likewise, the presence of flavonoid glycosides including isoquercetin, kaempferol-3-O-glucoside, apigenin-8-C- glucoside, quercetin 3-O-(6'-O-malonyl)-glucoside and kaempferol 3-O-(6'-O-malonyl)-glucoside has also been previously reported (Karthivashan et al., 2013; Kashiwada et al. 2011; Nouman et al. 2016; Vongsak et al. 2013).

In blanched leaf extract, the chromatogram was characterized by several altered peaks compared to fresh leaf extract. In addition, most phenolic compounds in the chromatogram of blanched leaf extract were present in traces except for compound No 8 (Fig. 6e) characterized by a retention time of $5.54 \mathrm{~min}$, which appeared as the major compound and was identified as isoquercetin based on the $\mathrm{m} / \mathrm{z}$ value and MS fragments (Table 7 ). 


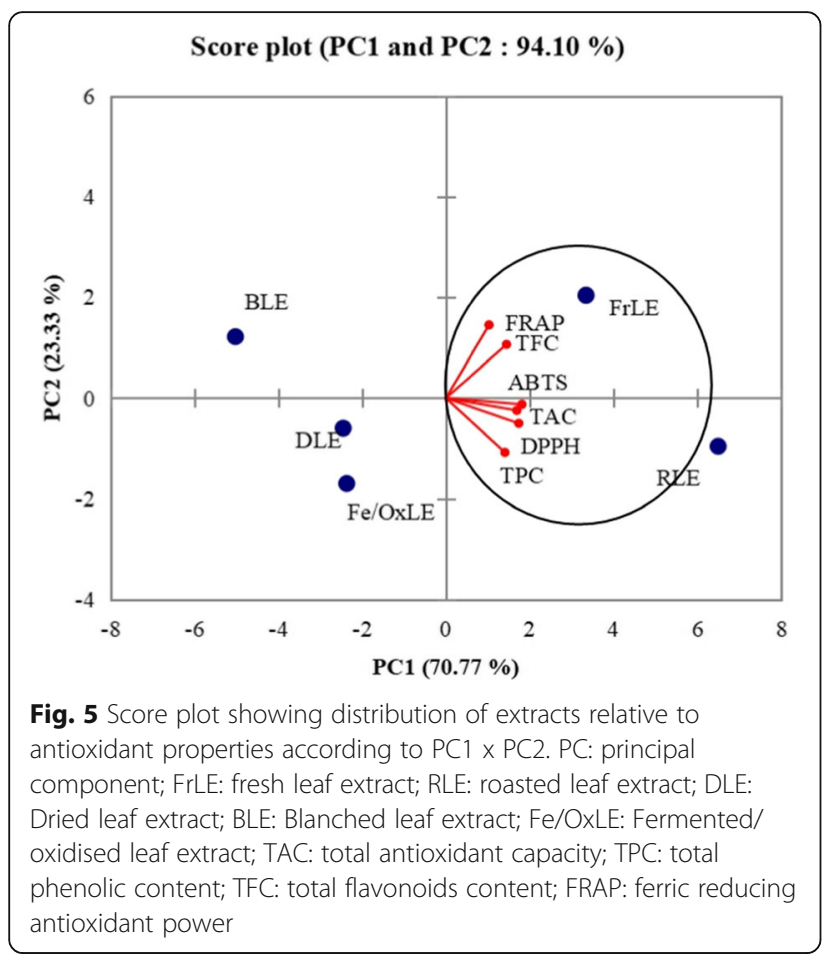

The altered peaks in the phenolic profile of blanched leaf extract present evidence of degradation of phenolic compounds in Moringa leaves during steam blanching, in accordance with the pattern observed for the phenolic content and total antioxidant activity where blanched Moringa leaf extract presented a significantly lower phenolic content and antioxidant activity compared to the fresh leaf extract.

The new compounds identified in roasted leaves (Quercetin-3-O-acetyl glucoside and Quercetine-3-Orhamnoside), are flavonoids with proven AOA potential (Valentová et al. 2014) and may thus be responsible for the increased AOA observed in roasted leaf extract. Major phenolics identified in roasted Moringa leaf extract were Rutin $(45 \mathrm{mg} / \mathrm{g})$, Quercetin $(15 \mathrm{mg} / \mathrm{g})$, Isoquercertin $(10 \mathrm{mg} / \mathrm{g})$ and Caffeic acid $(9 \mathrm{mg} / \mathrm{g})$.

\section{Conclusion}

Phenolic content, profile and antioxidant activity of Moringa leaves are influenced by the processing treatment applied to them. The optimal conditions of temperature and time for the post-harvest processing of Moringa oleifera leaves are $\left[92-96^{\circ} \mathrm{C}, 5-10 \mathrm{~min}.\right],\left[25-30{ }^{\circ} \mathrm{C}, 15-35 \mathrm{~min}\right.$.], [55-65 $\left.{ }^{\circ} \mathrm{C}, 205-210 \mathrm{~min}.\right],\left[140-150^{\circ} \mathrm{C}, 23-25 \mathrm{~min}\right.$.] respectively for steam blanching, oxidation, drying and roasting. The roasting of Moringa oleifera leaves resulted in significant increase in total phenolic content and antioxidant activity. The improvement of phytochemical content in roasted leaves was accompanied by the occurrence of 2 new compounds, identified as quercetin-3-O-
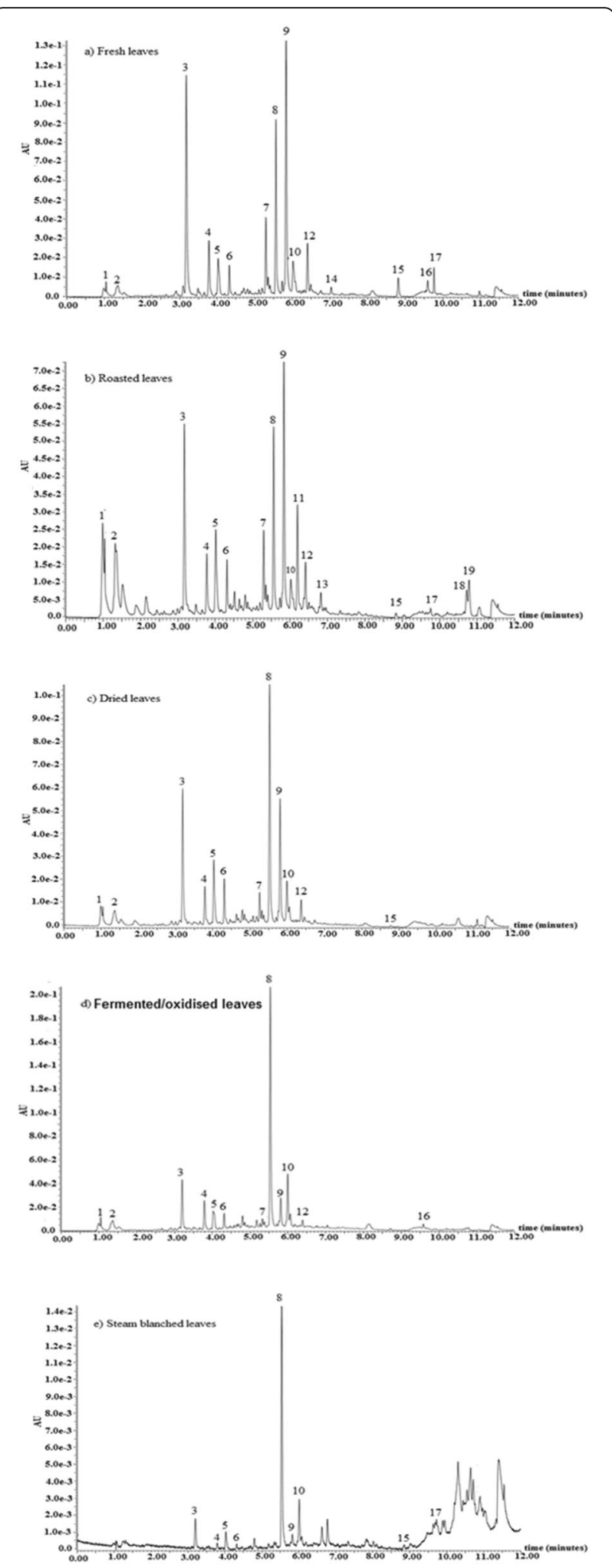

Fig. 6 LC-MS/MS phenolic profile of processed Moringa leaf extract a fresh leaves; $\mathbf{b}$ roasted leaves; $\mathbf{c}$ dried leaves; $\mathbf{d}$ fermented/oxidised leaves; e steam blanched leaves 
Table 7 Tentative identification of main polyphenols in chromatographs of Moringa oleifera fresh and processed Leaf Extract

\begin{tabular}{|c|c|c|c|c|c|c|c|c|c|c|}
\hline No & $\begin{array}{l}\mathrm{RT} \\
(\min .)\end{array}$ & $\begin{array}{l}\text { Mass } \\
(\mathrm{m} / \mathrm{z})\end{array}$ & Diagnostic fragments & $\begin{array}{l}\text { Peak } \\
\text { fragment }\end{array}$ & Fresh & Roasted & Dried & $\begin{array}{l}\text { Fermented/ } \\
\text { Oxidised }\end{array}$ & Blanched & Identity \\
\hline 1 & 1.05 & & $248 ; 325 ; 381 ; 448 ; 523 ; 723$ & 381 & $\checkmark$ & $\checkmark$ & $\checkmark$ & $\checkmark$ & & \\
\hline 2 & 1.36 & 432 & $\begin{array}{l}\text { 162; 180; 230; 253; 268; 270; 308; } \\
\text { 414; 432; 468 } \\
\text { Apigenin }(270)+\text { glucosyl }(162)=432\end{array}$ & 414,432 & $\checkmark$ & $\checkmark$ & $\checkmark$ & $\checkmark$ & & Apigenin glucoside \\
\hline 3 & 3.18 & 355 & $\begin{array}{l}\text { 163; 209; 227; 355; 379; 425; 726; } \\
732 \\
\text { Caffeoyl(162) + quinic acid }(192)=354\end{array}$ & 163 & $\checkmark$ & $\checkmark$ & $\checkmark$ & $\checkmark$ & $\checkmark$ & $\begin{array}{l}\text { Caffeoylquinic acid } \\
\text { (chlorogenic acid) }\end{array}$ \\
\hline 4 & 3.78 & 339 & $\begin{array}{l}\text { 147; 165; 227; 339; 419; 457; 499; } \\
\text { 541; 595; 701 } \\
\text { Coumaroyl (147) }\end{array}$ & 147 & $\checkmark$ & $\checkmark$ & $\checkmark$ & $\checkmark$ & $\checkmark$ & Coumaroylquinic acid \\
\hline 5 & 4.03 & 355 & $\begin{array}{l}\text { 147; 163; 177; 209; 341; 355; 369; } \\
\text { 579 } \\
\text { Caffeoyl(162) + quinic acid }(192)=354\end{array}$ & 163 & $\checkmark$ & $\checkmark$ & $\checkmark$ & $\checkmark$ & $\checkmark$ & $\begin{array}{l}\text { Caffeoylquinic acid } \\
\text { (chlorogenic acid) }\end{array}$ \\
\hline 6 & 4.32 & & $\begin{array}{l}163 ; 209 ; 227 ; 295 ; 322 ; 340 ; 457 ; \\
511 ; 557 ; 577 ; 595\end{array}$ & 595 & $\checkmark$ & $\checkmark$ & $\checkmark$ & $\checkmark$ & $\checkmark$ & \\
\hline 7 & 5.29 & 611 & $\begin{array}{l}\text { 147; 163; 180; 303; 435; 449; 453; } \\
465 ; 611 \\
\text { Quercetin (303) + rhamnosyl } \\
(146)=449 \\
\text { Quercetin(303) + glucosyl }(162)=465 \\
+ \text { rhamnosyl }(146)=611\end{array}$ & 303 & $\checkmark$ & $\checkmark$ & $\checkmark$ & $\checkmark$ & & Rutin \\
\hline 8 & 5.56 & 465 & $\begin{array}{l}\text { 303; } 465 \\
\text { Quercetin (303) + glucosyl }(162)=465\end{array}$ & 303 & $\checkmark$ & $\checkmark$ & $\checkmark$ & $\checkmark$ & $\checkmark$ & $\begin{array}{l}\text { Isoquercetin } \\
\text { (Querctin-3-O- } \\
\text { glucoside) }\end{array}$ \\
\hline 9 & 5.83 & 551 & $\begin{array}{l}303 ; 551 ; 635 \\
\text { Quercetin = } 303+\text { Malonyl-glucosyl } \\
(248)=551\end{array}$ & 303 & $\checkmark$ & $\checkmark$ & $\checkmark$ & $\checkmark$ & $\checkmark$ & $\begin{array}{l}\text { Quercetin-3-O- } \\
\text { malonyl-glucoside }\end{array}$ \\
\hline 10 & 6.02 & 449 & $\begin{array}{l}\text { 147; 180: 191; 196; 210; 230; } \\
\text { 235; 249; 265; 270; 276; 287; } \\
\text { 449; 551; 637; 679; } 875 \\
\text { Kaempferol } \\
(287)+\text { glucosyl }(162)=449+230= \\
679\end{array}$ & 287 & $\checkmark$ & $\checkmark$ & $\checkmark$ & $\checkmark$ & $\checkmark$ & $\begin{array}{l}\text { Kaempferol-3-O- } \\
\text { glucoside }\end{array}$ \\
\hline 11 & $\begin{array}{l}6.20 \\
\text { (roasted) }\end{array}$ & 507 & $\begin{array}{l}\text { 180; 187; 205; 222; 303; 327; 345; } \\
507 ; 529 \\
\text { Glucosyl(162) + acetyl(42) = } 204 \\
\text { glucosyl }(162)+\mathrm{Na}(23)=185 \\
\text { glucose }(180)+\text { acetyl }(42)=222 \\
\text { quercetin(303) + acetyl(42) = } 345 \\
\text { quercetin(303) } \mathrm{Na}(23)=326 \\
\text { Quercetin(303)+ Glucosyl-acetyl(204) } \\
=507+\mathrm{Na}(23)=530\end{array}$ & 303 & & $\checkmark$ & & & & $\begin{array}{l}\text { Quercetin-3-O-acetyl } \\
\text { glucoside } \\
\text { (Na salt) }\end{array}$ \\
\hline 12 & 6.40 & 535 & $\begin{array}{l}\text { 287; } 535 \\
\text { Kaempferol(287); } \\
\text { Malonyl-glucoside }=248 \\
535-287=248\end{array}$ & 287 & $\checkmark$ & $\checkmark$ & $\checkmark$ & $\checkmark$ & & $\begin{array}{l}\text { Kaempferol-3-O- } \\
\text { malonyl-glucoside }\end{array}$ \\
\hline 13 & 6.82 & 491 & $\begin{array}{l}287 ; 491 ; 513 \\
\text { Kaempferol }(287)+ \\
\text { Glucosyl-acetyl }(204)=491\end{array}$ & 287 & & $\checkmark$ & & & & $\begin{array}{l}\text { Kaempferol-3-O- } \\
\text { acetylglucoside } \\
543 \text { (Na salt) }\end{array}$ \\
\hline 14 & 10.72 & 593 & 593 & 593 & $\checkmark$ & & & & & $\begin{array}{l}\text { Quercetin-3-O- } \\
\text { rhamnoside }\end{array}$ \\
\hline 15 & & & $635 ; 778 ; 1269$ & 635 & $\checkmark$ & $\checkmark$ & $\checkmark$ & & $\checkmark$ & \\
\hline 16 & & & & & $\checkmark$ & & & $\checkmark$ & & \\
\hline 17 & & & & & $\checkmark$ & $\checkmark$ & & & $\checkmark$ & \\
\hline 18 & & & & & & $\checkmark$ & & & & \\
\hline 19 & & & & & & $\checkmark$ & & & & \\
\hline
\end{tabular}


acetylglucoside and Quercetine-3-O-rhamnoside. Roasting, thus, appears to be the most appropriate post-harvest treatment for improvement of antioxidant activity in Moringa oleifera leaves. Steam blanching on the other hand is deleterious to both phenolic components and antioxidant activity in Moringa oleifera leaves. On the whole, postharvest treatments affect qualitatively and quantitatively the phytochemical profile of Moringa oleifera leaves.

\section{Acknowledgements}

The authors gratefully acknowledge The World Academy of Science (TWAS) and the Council for Scientific and Industrial Research (CSIR) for TWAS-CSIR postgraduate fellowship program (FR number: 3240280447 to Mr. Nobossé). The authors are also grateful to the Director, CSIR-Institute of Himalayan Bioresource Technology, Palampur, H.P. India for providing the research facilities.

\section{Authors' contributions}

NP was involved in the conception of the study, sample preparation, laboratory analysis, data analysis, data interpretation, data presentation and drafting of the manuscript. EFN was involved the conception of the study, supervision of laboratory analysis, data interpretation, data presentation and correction of manuscript. CMFM participated in the study design, data analysis, data interpretation and review of the manuscript. DS was involved in the study design, supervised laboratory analysis and reviewed the manuscript. The author(s) read and approved the final manuscript.

\section{Funding}

TWAS-CSIR postgraduate fellowship program (FR number: 3240280447 to Mr. Nobossé).

\section{Availability of data and materials}

All data generated during this study are available in the manuscript.

\section{Declarations}

Ethics approval and consent to participate

Not applicable.

\section{Consent for publication}

Not applicable.

\section{Competing interests}

The authors declare they have no competing interests.

\section{Author details}

${ }^{1}$ Department of Food Science and Nutrition, National School of Agro-Industrial Sciences, ENSAI, University of Ngaoundere, P.O. Box 455, Ngaoundere, Adamawa Region, Cameroon. ${ }^{2}$ Pharmacology and Toxicology Laboratory, CSIR-Institute of Himalayan Bioresource Technology, Palampur, Himachal Pradesh 176061, India.

\section{Received: 31 March 2021 Accepted: 16 June 2021}

Published online: 11 August 2021

\section{References}

Adefegha, S. A., \& Oboh, G. (2011). Enhancement of total phenolics and antioxidant properties of some tropical green leafy vegetables by steam cooking. Journal of Food Processing and Preservation, 35, 615-622. https://doi. org/10.1111/j.1745-4549.2010.00509.x.

Agamou, J. A. A., Fombang, E. N., \& Mbofung, C. M. F. (2015). Particular benefits can be attributed to Moringa oleifera lam leaves based on origin and stage of maturity. Journal of Experimental Biology and Agricultural Sciences, 3(6), 541-555. https://doi.org/10.18006/2015.3(6).541.555.

Al-Juhaimi, F., Ghafoor, K., Özcan, M. M., Jahurul, M. H. A., Babiker, E. E., Jinap, S., . Zaidul, I. S. M. (2018). Effect of various food processing and handling methods on preservation of natural antioxidants in fruits and vegetables. Journal of Food Science and Technology, 55(10), 3872-3880. https://doi.org/1 0.1007/s13197-018-3370-0.
Amin, I., Norazaidah, Y., \& Hainida, K. I. (2006). Antioxidant activity and phenolic content of raw and blanched Amaranthus species. Food Chemistry, 94, 47-52 https://doi.org/10.1016/j.foodchem.2004.10.048.

Barek, M. L., Hasmadi, M., Zaleha, A. Z., \& Fadzelly, A. B. M. (2015). Effect of different drying methods on phytochemicals and antioxidant properties of unfermented and fermented teas from Sabah Snake Grass (Clinacanthus nutans Lind.) leaves. International Food Research Journal, 22, 661-670.

Bas, D., \& Boyacı, İ. H. (2007). Modeling and optimization I: Usability of response surface methodology. Journal of Food Engineering, 78, 836-845. https://doi. org/10.1016/j.jfoodeng.2005.11.024.

Singh, B.N., Singh, B.R., Singh, R.L., Prakash, D., Dhakarey, R., Upadhyay, G. and Singh, H.B. (2009). Oxidative DNA damage protective activity, antioxidant and anti-quorum sensing potentials of Moringa oleifera. Food and chemical toxicology 47,6,1109-1116. https://doi.org/10.1016/j.fct.2009.01.034.

Brand-Williams, W., Cuvelier, S. E., \& Berset, C. (1995). Use of a free radical method to evaluate antioxidant activity. Lebensmittel-Wissenschaft + Technologie, 28, 25-30. https://doi.org/10.1016/S0023-6438(95)80008-5.

Chen, C. P., Yokozawa, T., \& Chung, H. Y. (1999). Inhibitor effect of caffeic acid analogs isolated from Salviae miltiorrhizae radix against 1,1-diphenyl-2picrylhydrazil radical. Experimental and Toxicologic Pathology, 51, 59-63. https://doi.org/10.1016/S0940-2993(99)80066-9.

Chumark, P., Khunawat, P., Sanvarinda, Y., Phornchirasilp, S., Morales, N. P., Phivthong-ngam, L., ... Pongrapeeporn, K. S. (2008). The in vitro and ex vivo antioxidant properties, hypolipidaemic and antiatherosclerotic activities of water extract of Moringa oleifera Lam. leaves. Journal of Ethnopharmacology, 116(3), 439-446. https://doi.org/10.1016/j.jep.2007.12.010.

Feumba Dibanda, R., Panyoo Akdowa, E., Rani, P. A., Metsatedem Tongwa, Q., \& Mbofung, F. C. M. (2020). Effect of microwave blanching on antioxidant activity, phenolic compounds and browning behaviour of some fruit peelings. Food Chemistry, 302, 125308. https://doi.org/10.1016/j.foodchem.201 9.125308.

Gonçalves, E. M., Pinheiro, J., Abreu, M., Brandão, T. R. S., \& Silva, C. L. M. (2010). Carrot (Daucus carota L.) peroxidase inactivation, phenolic content and physical changes kinetics due to blanching. Journal of Food Engineering, 97(4), 574-581. https://doi.org/10.1016/j.jfoodeng.2009.12.005.

Gopalakrishnan, L., Doriya, K., \& Kumar, D. S. (2016). Moringa oleifera: A review on nutritive importance and its medicinal application. Food Science and Human Wellness, 5, 49-56. https://doi.org/10.1016/j.fshw.2016.04.001.

Heong, C. S., Kaur, B., Huda, N., Karim, A. A., \& Fazilah, A. (2011). Effect of Fermentation on the Composition of Centella asiatica Teas. American Journal of Food Technology, 6(7), 581-593. https://doi.org/10.3923/ajft.2011.581.593.

Irondi, E. A., Akintunde, J. K., Agboola, S. O., Boligon, A. A., \& Athayde, M. L. (2016). Blanching influences the phenolics composition, antioxidant activity, and inhibitory effect of Adansonia digitataleaves extract ona-amylase, aglucosidase, and aldose reductase. Food Science \& Nutrition, 5(2), 233-242. https://doi.org/10.1002/fsn3.386,2017.

Jaiswal, A. K., Gupta, S., \& Abu-Ghannam, N. (2012). Kinetic evaluation of colour, texture, polyphenols and antioxidant capacity of Irish York cabbage after blanching treatment. Food Chemistry, 131(1), 63-72. https://doi.org/10.1016/j. foodchem.2011.08.032

Jaiswal, D., Rai, P. K., Mehta, S., Chatterji, S., Shukla, S., Rai, D. K., ... Watal, G. (2013). Role of Moringa oleifera in regulation of diabetes-induced oxidative stress. Asian Pacific Journal of Tropical Medicine, 6(6), 426-432. https://doi. org/10.1016/s1995-7645(13)60068-1.

Jeong, S. M., Kim, S. Y., Kim, D. R., Nam, K. C., Ahn, D. U., \& Lee, S. C. (2004). Effect of seed roasting conditions on the antioxidant activity of defatted sesame meal extracts. Journal of Food Science, 69(5), 377-381. https://doi.org/10.1111/ j.1365-2621.2004.tb10701.x.

Juániz, I., Ludwig, I. A., Huarte, E., Pereira-Caro, G., Moreno-Rojas, J. M., Cid, C., \& De Peña, M.P. (2016). Influence of heat treatment on antioxidant capacity and (poly) phenolic compounds of selected vegetables. Food Chemistry, 197, 466-473. https://doi.org/10.1016/j.foodchem.2015.10.139.

Karthivashan, G., Tangestani Fard, M., Arulselvan, P., Abas, F., \& Fakurazi, S. (2013) Identification of Bioactive Candidate Compounds Responsible for Oxidative Challenge from Hydro-Ethanolic Extract of Moringa oleifera Leaves. Journal of Food Science, 78(9), C1368-C1375. https://doi.org/10.1111/1750-3841.12233.

Kashiwada, Y., Ahmed, F. A., Kurimoto, S., Kim, S.-Y., Shibata, H., Fujioka, T., \& Takaishi, Y. (2011). New a-glucosides of caffeoyl quinic acid from the leaves of Moringa oleifera Lam. Journal of Natural Medicines, 66(1), 217-221. https:// doi.org/10.1007/s11418-011-0563-5. 
Kim, Y., Goodner, K. L., Park, J.-D., Choi, J., \& Talcott, S. T. (2011). Changes in antioxidant phytochemicals and volatile composition of Camellia sinensis by oxidation during tea fermentation. Food Chemistry, 129(4), 1331-1342. https:// doi.org/10.1016/j.foodchem.2011.05.012.

Kongpichitchoke, T., Chiu, M.-T., Huang, T.-C., \& Hsu, J.-L. (2016). Gallic Acid Content in Taiwanese Teas at Different Degrees of Fermentation and Its Antioxidant Activity by Inhibiting PKC $\delta$ Activation: In Vitro and in Silico Studies. Molecules, 21(10), 1346. https://doi.org/10.3390/molecules21101346.

Makita, C., Chimuka, L., Steenkamp, P., Cukrowska, E., \& Madala, E. (2016). Comparative analyses of flavonoid content in Moringa oleifera and Moringa ovalifolia with the aid of UHPLC-qTOF-MS fingerprinting. South African Journal of Botany, 105, 116-122. https://doi.org/10.1016/j.sajb.2015.12.007.

Miglio, C., Chiavaro, E., Visconti, A., Fogliano, V., \& Pellegrini, N. (2008). Effects of Different Cooking Methods on Nutritional and Physicochemical Characteristics of Selected Vegetables. Journal of Agricultural and Food Chemistry, 56(1), 139-147. https://doi.org/10.1021/jf072304b.

Moodley, T., Amonsou, E. O., \& Kumar, S. (2015). Nutritional quality and acceptability of Buddleja saligna herbal tea. Journal of Food Science and Technology, 52(11), 7519-7524. https://doi.org/10.1007/s13197-015-1870-8.

Moyo, S. M., Mavumengwana, V., \& Kayitesi, E. (2017). Effects of cooking and drying on phenolic compounds and antioxidant activity of African green leafy vegetables. Food Reviews International. Advance online publication. https://doi.org/10.1080/87559129.2017.1289384.

Myers, R. M., \& Montgomery, D. C. (2002). Response surface methodology : process and product optimization using designed experiments, (2nd ed., ). Wiley.

Ncube, E. N., Mhlongo, M. I., Piater, L. A., Steenkamp, P. A., Dubery, I. A., \& Madala, N. E. (2014). Analyses of chlorogenic acids and related cinnamic acid derivatives from Nicotiana tabacumtissues with the aid of UPLC-QTOF-MS/ MS based on the in-source collision-induced dissociation method. Chemistry Central Journal, 8(1). https://doi.org/10.1186/s13065-014-0066-z.

Ng, Z. X., \& See, A. N. (2019). Effect of in vitro digestion on the total polyphenol and flavonoid, antioxidant activity and carbohydrate hydrolyzing enzymes inhibitory potential of selected functional plant-based foods. Journal of Food Processing and Preservation, 43(4), e13903. https://doi.org/10.1111/jfpp.13903.

Ng, Z. X., Than, M. J. Y., \& Yong, P. H. (2021). Peperomia pellucida (L.) Kunth herbal tea: Effect of fermentation and drying methods on the consumer acceptance, antioxidant and anti-inflammatory activities. Food Chemistry, 344, 128738. https://doi.org/10.1016/j.foodchem.2020.128738.

Nobossé, P., Fombang, E. N., \& Mbofung, C. M. F. (2017). The effect of steam blanching and drying method on nutrients, phytochemicals and antioxidant activity of Moringa (Moringa oleifera L.) leaves. American Journal of Food Science and Technology, 5(2), 53-60. https://doi.org/10.12691/ajfst-5-2-4.

Nobossé, P. N., Fombang, E. N., \& Mbofung, C. M. F. (2018). Effects of age and extraction solvent on phytochemical content and antioxidant activity of fresh Moringa oleifera L. Leaves. Food Science \& Nutrition, 6, 2188-2198. https://doi. org/10.1002/fsn3.783.

Nouman, W., Anwar, F., Gull, T., Newton, A., Rosa, E., \& Domínguez-Perles, R. (2016). Profiling of polyphenolics, nutrients and antioxidant potential of germplasm's leaves from seven cultivars of Moringa oleifera Lam. Industrial Crops and Products, 83, 166-176. https://doi.org/10.1016/j.indcrop.2015.12.032.

Oboh, G. (2005). Effect of blanching on the antioxidant properties of some tropical green leafy vegetables. LWT - Food Science and Technology, 38(5), 513-517. https://doi.org/10.1016/j.lwt.2004.07.007.

Palermo, M., Pellegrini, N., \& Fogliano, V. (2013). The effect of cooking on the phytochemical content of vegetables. Journal of the Science of Food and Agriculture, 94(6), 1057-1070. https://doi.org/10.1002/jsfa.6478.

Parwani, L., Bohra, Y., Gupta, S., \& Kumar, R. (2016). Effect of temperature on aglucosidase, lipase inhibition activity and other nutritional properties of Moringa oleifera leaves intended to be used as daily antidiabetic therapeutic food. Journal of Food and Nutrition Research, 55(1), 69-77.

Pellegrini, N., Chiavaro, E., Gardana, C., Mazzeo, T., Contino, D., Gallo, M., .. Porrini, M. (2010). Effect of different cooking methods on color, phytochemical concentration, and antioxidant capacity of raw and frozen Brassica vegetables. Journal of Agricultural and Food Chemistry, 58, 4310-4321. https://doi.org/10.1021/jf904306r

Potisate, Y., Phoungchandang, S., \& Kerr, W. L. (2014). The Effects of Predrying Treatments and Different Drying Methods on Phytochemical Compound Retention and Drying Characteristics of Moringa Leaves (Moringa oleifera Lam.). Drying Technology, 32(16), 1970-1985. https://doi.org/10.1080/0737393 7.2014.926912
Prieto, P., Pineda, M., \& Aguilar, M. (1999). Spectrophotometric quantitation of antioxidant capacity through the formation of phosphomolybdenum complex: Specific application to determination of vitamin E. Analytical Biochemistry, 269, 337-341. https://doi.org/10.1006/abio.1999.4019.

Re, R., Pellegrini, N., Proteggente, A., Pannala, A., Yang, M., \& Rice-Evans, C. (1999). Antioxidant activity applying an improved ABTS radical cation decolorization assay. Free Radical Biology and Medicine, 26(9-10), 1231-1237. https://doi. org/10.1016/s0891-5849(98)00315-3.

Rodríguez-Pérez, C., Quirantes-Piné, R., Fernández-Gutiérrez, A., \& SeguraCarretero, A. (2015). Optimization of extraction method to obtain a phenolic compounds-rich extract from Moringa oleifera Lam leaves. Industrial Crops and Products, 66, 246-254. https://doi.org/10.1016/j.indcrop.2015.01.002.

Samanta, T., Cheeni, V., Das, S., Roy, A. B., Ghosh, B. C., \& Mitra, A. (2013). Assessing biochemical changes during standardization of fermentation time and temperature for manufacturing quality black tea. Journal of Food Science and Technology, 52(4), 2387-2393. https://doi.org/10.1007/s13197-013-1230-5.

Shin, E.-C., Craft, B. D., Pegg, R. B., Phillips, R. D., \& Eitenmiller, R. R. (2010). Chemometric approach to fatty acid profiles in Runner-type peanut cultivars by principal component analysis (PCA). Food Chemistry, 119(3), 1262-1270. https://doi.org/10.1016/j.foodchem.2009.07.058.

Valentová, K., Vrba, J., Bancírová, M., Ulrichová, J., \& Křen, V. (2014). Isoquercitrin: Pharmacology, toxicology, and metabolism. Food and Chemical Toxicology, 68, 267-282. https://doi.org/10.1016/j.fct.2014.03.018.

Verma, A. R., Vijayakumar, M., Mathela, C. S., \& Rao, C. V. (2009). In vitro and in vivo antioxidant properties of different fractions of Moringa oleifera leaves. Food and Chemical Toxicology: An International Journal Published for the British Industrial Biological Research Association, 47(9), 2196-2201. https://doi. org/10.1016/j.fct.2009.06.005.

Vongsak, B., Sithisarn, P., Mangmool, S., Thongpraditchote, S., Wongkrajang, Y., \& Gritsanapan, W. (2013). Maximizing total phenolics, total flavonoids contents and antioxidant activity of Moringa oleifera leaf extract by the appropriate extraction method. Industrial Crops and Products, 44, 566-571. https://doi. org/10.1016/j.indcrop.2012.09.021.

Wang, H., Fang, X.-M., Sutar, P. P., Meng, J.-S., Wang, J., Yu, X.-L., \& Xiao, H.-W. (2021). Effects of vacuum-steam pulsed blanching on drying kinetics, colour, phytochemical contents, antioxidant capacity of carrot and the mechanism of carrot quality changes revealed by texture, microstructure and ultrastructure. Food Chemistry, 338, 127799. https://doi.org/10.1016/j. foodchem.2020.127799.

Yu, J., Ahmedna, M., \& Goktepe, I. (2005). Effects of processing methods and extraction solvents on concentration and antioxidant activity of peanut skin phenolics. Food Chemistry, 90(1-2), 199-206. https://doi.org/10.1016/j. foodchem.2004.03.048.

Zhang, R., Zhang, B.-L., He, T., Yi, T., Yang, J.-P., \& He, B. (2016). Increase of rutin antioxidant activity by generating Maillard reaction products with lysine. Bioorganic \& Medicinal Chemistry Letters, 26(11), 2680-2684. https://doi.org/1 0.1016/j.bmcl.2016.04.008.

Zhang, X., \& Shao, X. (2016). Characterisation of polyphenol oxidase and peroxidase and the role in browning of loquat fruit. Czech Journal of Food Sciences, 33(2), 109-117. https://doi.org/10.17221/384/2014-cjfs.

\section{Publisher's Note}

Springer Nature remains neutral with regard to jurisdictional claims in published maps and institutional affiliations.

Ready to submit your research? Choose BMC and benefit from:

- fast, convenient online submission

- thorough peer review by experienced researchers in your field

- rapid publication on acceptance

- support for research data, including large and complex data types

- gold Open Access which fosters wider collaboration and increased citations

- maximum visibility for your research: over $100 \mathrm{M}$ website views per year

At BMC, research is always in progress.

Learn more biomedcentral.com/submissions 